\title{
Rehabilitation of Polluted Urban Areas
}

\author{
Galitskova Yu.M., Balzannikov M.I., Vyshkin E.G. \\ Samara State Technical University, Institute of Architecture and Civil Engineering \\ Address: Molodogvardeyskaya St., 194, Samara, 443001, Russia
}

\begin{abstract}
Industrial structures, residential buildings and other objects of infrastructure are being constructed in many Russian cities now. In addition to new constructions, reconstruction and rebuilding of existing buildings is also being performed. Meanwhile, such construction objects are situated not only in open suburban areas but also in urban districts and city zones. Often it is necessary to dismantle or demolish old run-down buildings or distressed structures before constructing new buildings. Such works always cause large amounts of construction waste.

To accommodate constructive materials for new structures and to store elements of disassembled buildings and construction wastes special storage grounds are used. Being of temporal nature, these storage grounds are not capable to ensure full protection of the environment from pollution.

The team of employees of Samara State Technical University investigated several districts of the city of Samara. This investigation revealed that in all temporary dumping sites construction wastes amount to $8 \%$ and dumping sites of a mixed type containing construction wastes - to $35 \%$.

The majority of temporary dumping sites are removed in a short time. Mostly, it is done by collection and removal of construction waste to special waste landfills. At the same time, the investigation demonstrated that though these dumping sites are temporal, their existence causes environmental pollution of underlying open ground as repugnant substance penetrates the ground with rains and pollution of airspace as light pollutants are dispersed by wind. Moreover, even after these temporary dumping sites are removed, already polluted soil layers continue to pollute soils as a secondary pollutant source.

The authors offer a technical solution which allow to carry out rehabilitation of polluted urban areas more effectively. In particular, it is recommended to remove waste from the temporary dumping sites stage by stage. At the first stage, offsite areas should be inspected and the extent of pollution (pollution depth) of underground layers should be estimated. At the next stage, a protective barrier in the ground around the dumping site and on the surface should be built. Only after that we recommend that wastes should be removed and sent to a waste recycling plant or to a specially equipped waste landfill. Then, it is required to cut off all polluted soils and to remove them to a special waste landfill for storage.

Thus, this solution makes it possible to reduce the risk of secondary environmental pollution.
\end{abstract}

Keywords: wastes, shell and core dumps, liquidation, land improvement.

\section{INTRODUCTION}

Change of urban development is marked as a result of acceleration of development of residential locations. At the same time more modern and comfortable buildings, serving and auxiliary facilities, such as shopping centers, parking areas and others are often constructed on the place of old dilapidated and obsolete buildings.

Renovation of real estate development is inseparably linked with release of the built-up territories and demolition of buildings that complicates the direct process of building and carrying out construction works in the restricted area.

The main method of collection and utilization of the buildings waste which is left after dismantle of buildings and constructions is warehousing directly on the building site within a certain yard territory [13].

The organization of collection and centralized export of construction waste in the restricted area is difficult, that leads to emerging shell and core dumps in the yards of residential quarters.
Infil construction leads to the urgent rise of question of emergence of such dumps, where the building site is located closely to private or country sector.

The general view of a shell and core dump is provided in Fig. 1.

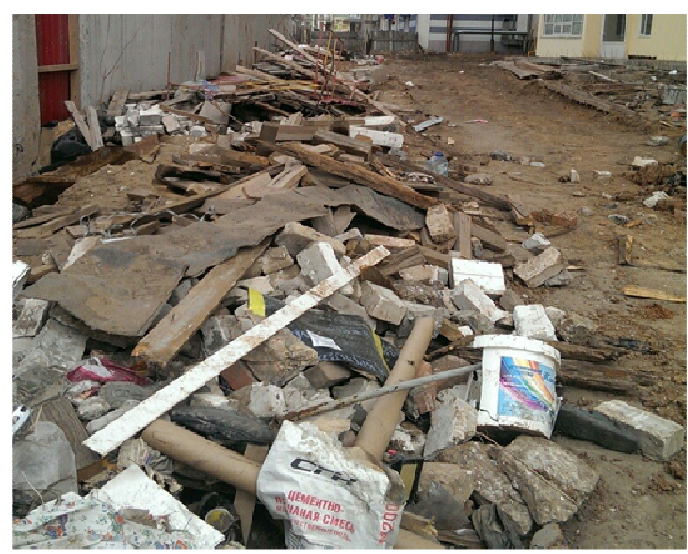

Fig. 1. Shell and core dump of construction waste 
It should be noted that on the territory of the city there are not only dumps of construction waste, but also shell and core dumps of household waste which are quite often located near construction wastes.

\section{MATERIALS AND METHODS \\ Construction Sites}

Staff of higher education institution together with a group of students made inspections of several districts of the city of Samara. During the research about 50 shell and core dumps were recorded and analysed.

Morphological structure shows the diversity of the studied dumps: dumps only with household waste constitute $57 \%$, building wastes $-8 \%$ and $35 \%$ of shell and core dumps are of the mixed type.

Construction dumps are formed, as a rule, nearby or directly to the construction site. Shell and core dumps with household waste are often located near a private sector or in the yards of multi-storied houses, where there are no equipped platforms in the yards for accumulating household waste or the schedule of export of waste by the municipal companies.

Shell and core dumps of the mixed type are of special interest. Their formation usually begins with lack of the built-up platform for building waste collection and its untimely export from the construction site territory. Then, eventually, construction waste begins "to mix" with the household waste made by inhabitants of adjacent residential buildings [4-6].

\section{Territory Pollution}

Emergence of shell and core dumps leads to littering of the urban area, loss of appeal of domestic sites, change of esthetic perception. Besides, waste leads to various ongoing processes. For example, such household waste as food can undergo the process of oxidation and filtrate formation. The filtrate, concentrated on the surfaces of the soil, pollutes it, getting to the top layers. The filtrate is also a source of an unpleasant smell near a dump and at the adjacent territory.

\section{Research}

Research of process of penetration of pollutants has been conducted in order to define the area of influence of a shell and core dump on the soil. Research was conducted on twelve substances. Tests of soil at different depths under a dump were made and quantitative characteristics were determined by the chosen substances.

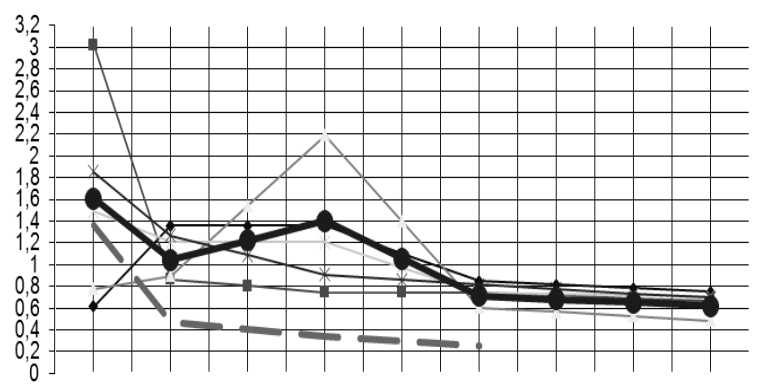

Fig. 2. Research results of soil pollution with cadmium

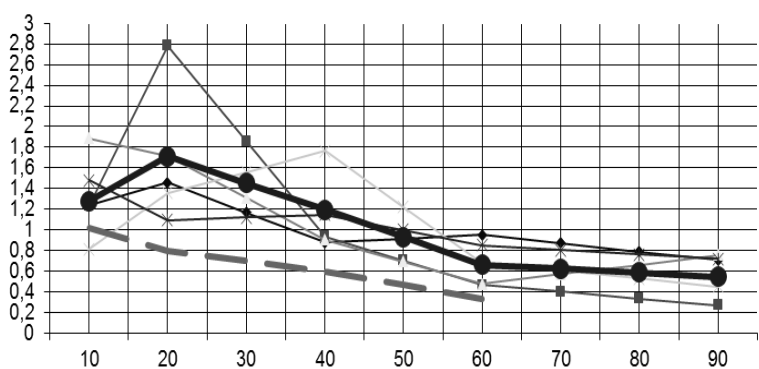

Fig. 3. Research results of soil pollution with copper

Research results of pollution of the soil by one of substances - cadmium are reflected in Fig. 2. The vertical axis shows amount of pollutant in $\mathrm{mg} / \mathrm{kg}$, a horizontal axis - depth of penetration of substance into soil. Apparently, the maximum quantity of pollutant was revealed on the soil surface.

Fig. 3 presents the results of copper penetration of into soil. It should be noted that for this substance the maximum sizes correspond to $10-15 \mathrm{~cm}$ depth.

One of the most dangerous pollutants is lead, by results of researches, concentrates at a depth of 15-20 $\mathrm{cm}$, at the same time the maximum depth of penetration of lead into soil is $35-40 \mathrm{~cm}$.

The analysis of other studied pollutants has shown approximately similar changes of quantitative characteristics with increase of depth of penetration into soil.

\section{RESULTS AND DISCUSSION}

Research has shown that the greatest pollution is concentrated on the top layer of earth which doesn't exceed, as a rule, $40-45 \mathrm{~cm}$. The amount of the concentrated pollutants depends not only on component structure of waste of a shell and core dump, but also on duration of a dump existence.

For prevention of pollution of soil as a result of emergence and development of shell and core dumps on the territory of the city, the stage-by-stage scheme of liquidation of the most shell and core dump (fig. 4), and also the polluted soil [7] has been developed. 


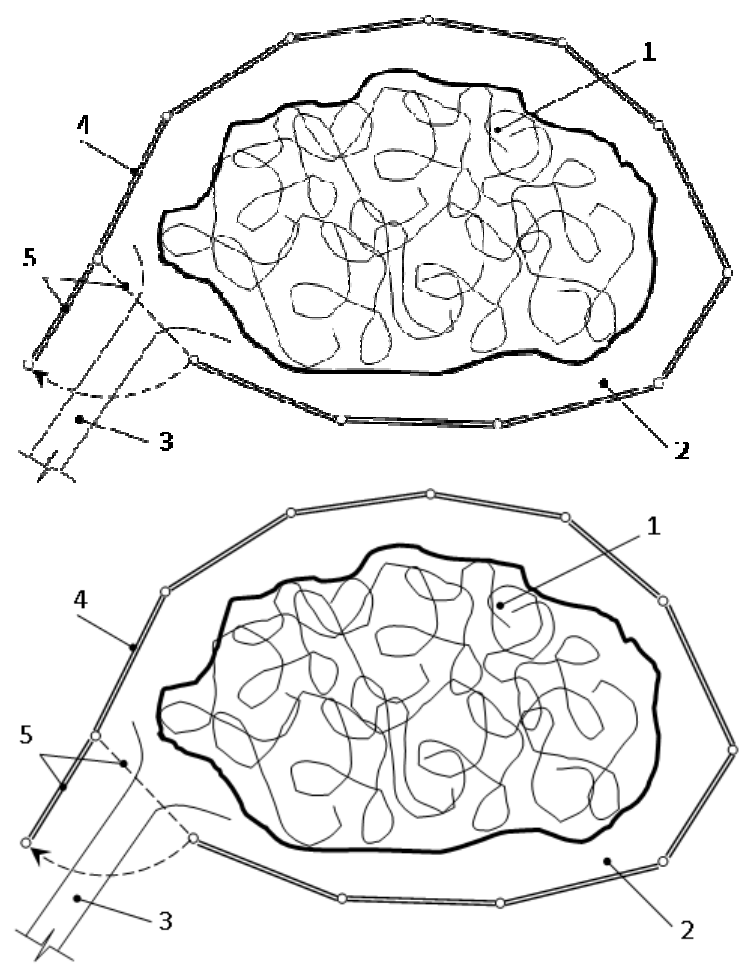

Fig. 4. The method of shell and core dump liquidation

1 - dump, 2 - dump territory, 3 - motor driveway, 4 protection barrier, 5 - the barrier's door open

As the origin of a dump is not always defined and depth of filtrate penetration is not calculated, it is necessary to conduct a territory research prior to dump liquidation. The natural research of the adjacent territory, and also chemical analysis of soil for definition of extent of pollution is conducted in order to start dump liquidation. In case of a possible high bedding of ground waters, it is also necessary to carry out chemical research of waters.

It is rational to install a protective barrier to prevent further penetration of pollutants. The barrier needs to be established both under, and over the Earth's surface. In soil - for restriction of distribution of pollution in soil, and also penetration of pollution into adjacent massifs. For this purpose the barrier is arranged deep into to a confining bed. The barrier over the Earth's surface prevents pollutants' transfer on the soil surface as a result of rain or animals life.

After installation of a barrier it is necessary to start liquidation of the dump. Waste is loaded on a specialized transport and taken out to the testing area for further utilization.

During the full removal of a waste layer, it is necessary to carry out removal of the polluted soil as well. Power of the liquidated layer is determined by results of the research conducted earlier.

Besides cleaning of a surface of soil there happens its 'baring'. The pollutants concentrated on a surface, especially after rainy weather, have an opportunity to extend deeply. Installation of a tent that covers a dump within the established barrier is recommended for prevention of further pollution distribution.

After liquidation of a dump and polluted soil, improvement of the territory (fig. 5) is made: filling of formed cut by uncontaminated soil, and also, if necessary, arrangement of the stationary constant platform for household waste [8].

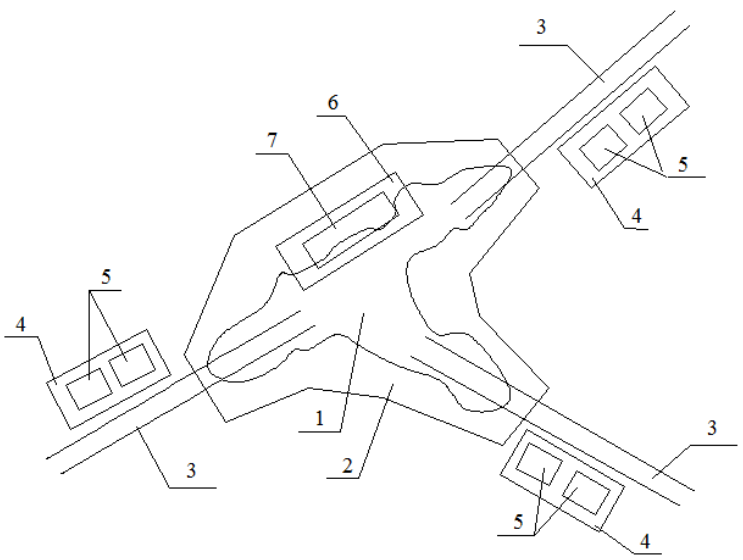

Fig. 5. Method of dump liquidation with further improvement 1 - dump, 2 - contaminated soil area, 3 - approach roadways, 4 - temporary special lands, 5 - temporary containers for household waste, 6 - stationary asphalted area, 7 - stationary containers for household waste

Also, it is possible to make implantation of green trees, to provide parking facilities, children or sports ground in order to improve the territory.

\section{CONCLUSION}

Timely export of waste, prevention of its long storage at construction sites or at the domestic territories is necessary for prevention of origin of shell and core dumps of construction wastes after dismantling of buildings and constructions, and also mixed and household waste. The organization of platforms for building wastes storage within the construction site territory combined with nature protection actions for minimization of negative impact of waste on the environment is also recommended.

It is necessary to liquidate already formed and existing dumps and carry out events for improvement of the cluttered-up territories, using the described method in this paper.

The method of shell and core dump liquidation will allow making the territory of the city more comfortable and attractive for living. Such approach of shell and core dumps liquidation of household waste will provide the slightest polluting impact on the adjacent territory. Application of the method is possible not only in megalopolises and large cities, but also in other populated areas. 


\section{V.ACKNOWLEDGMENTS}

This study was partly supported

\section{REFERENCES}

[1] Kravtsova M.V., Vasilyev A.V., Nagaitseva M.P., Kravtsov A.V. Nomenklaturniy analiz objemov obrazovaniya otkhodov stroitelstva i snosa [Nomenclature analysis of waste production volume and demolition]. Izvestiya Samarskogo nauchnogo zentra Rossiiskoi akademii nauk [Bulletin of Samara research center of Russian Academy of Sciences], 44, 2015, pp.810-816.

[2] Zhigulina A.Yu., Chumachenko N.G. Vybor stroitelnykh materialov dlya uluchsheniya komforta i ekologicheskoi bezopasnosti zhilya [Choice of construction materials for comfort improvement and ecological safety of a residential building]. Urban Construction and Architecture, 4 (21), 2015 , pp. 94-99.

[3] Kravtsov M.V., Vasilyev A.V., Kravtsov A.V., Nosarev N.S. Analis metodov utilizatsii otkhodov stroitelstva $\mathrm{S}$ posleduyuschim vovlecheniyem ikh vo vtorichniy oborot [Analysis of utilization methods of construction waste, using them in the secondary recovery]. Izvestiya Samarskogo nauchnogo zentra Rossiiskoi akademii nauk [Bulletin of Samara research center of Russian Academy of Sciences], V.17. 4-4, 2015, pp. 804-809.

[4] Maryin V.V., Risnik V.V., Pisarenko V.N., Timofeyev V.B., Shyshov V.P. O problem bytovykh otkhodov megapolisov i putyakh eye rescheniya [Problems of household waste in metropolitan areas and ways of its solution]. Gorniy infomatzionniy bulleten (naychno-tekhnicheskiy zhurnal [Gorniy information bulletin (research and technical journal)], V.2, 2000, pp.85-91.

[5] Kolychev N.A. Optimizatsiya obrascheniya s tevrdymi bytovymi i blizkimi $\mathrm{k}$ nim po sostavu promyschlennimy otkhodami krupnykh i srednikh nasellennykh punktov Rossii [Optimization of processing firm household and similar in structure industrial wastes of large and average populated areas of Russia]. Biosphera [Biosphere], V.5, 4, 2013, pp. 393-418.

[6] Malakhov V.M. Gritsenko V.M., Druzhinin S.V. Gorodskiye otkhody v Rossii: sostoyaniye, problemy, puti rescheniya [Urban waste in Russia: current situation, problems, ways of solution]. Ekologiya. Seriya analitecheskikh obzorov mirovoi literatury [Ecology. Series of analytical review of world literature], 98, 2012, pp.1-126.

[7] Balzannikov M.I., Galitskova Yu.M. Sposob zaschity okruzhauschei sredy ot zagryazneniy bytovimy i promyshlennimy otkhodami [Method of environmental protection from pollutants of household and industrial waste]. Patent RF, 2294245, 2007, Bul. № 6.

[8] Balzannikov M.I., Galitskova Yu.M. Sposob zaschity okruzhauschei sredy ot zagryazneniya tverdimy bytovimy otkhodami [Method of environmental protection from pollution by solid household waste]. Patent RF, 2372154, 2009, Bul. № 6. 